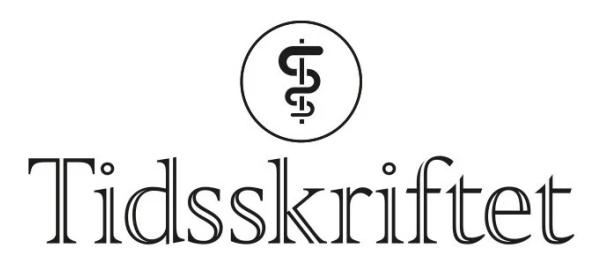

DEN NORSKE LEGEFORENING

\title{
Hallvard Holdaas
}

\author{
MINNEORD
}

ANDERS HARTMANN

ANNA VARBERG REISATER

\section{KARSTEN MIDTVEDT}

\section{PÅL-DAG LINE}

Avdeling for transplantasjonsmedisin

og

Institutt for klinisk medisin

Universitetet i Oslo

Han har bidratt med informasjon/data om kirurgiske delen av prosjektet og har revidert og godkjent innsendte manuskriptversjon.

Pål-Dag Line (f. 1960) er professor II i kirurgi, spesialist i generell kirurgi og i karkirurgi, har europeisk sertifisering i abdominal transplantasjonskirurgi og er avdelingssjef. Han er norsk styremedlem i Scandiatransplant.

Forfatter har fylt ut ICMJE-skjemaet og oppgir ingen interessekonflikter.

\section{TROND GEIR JENSSEN}

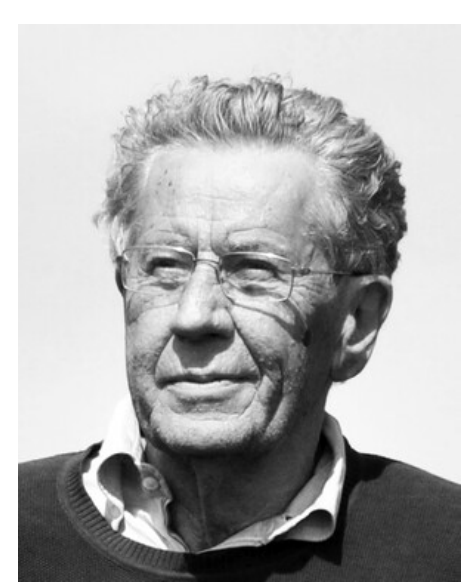

En nær venn og sentral person i Norges transplantasjonsmiljø gikk bort 17. juni, 74 år gammel. Hallvard var nyrelege og forsvarte sin doktorgrad i nyrefysiologi i 1984. Han ble ansatt ved Rikshospitalets nyreseksjon i 1985 og ble der til pensjonsalder. Rikshospitalet 
har landsfunksjon for transplantasjon og er et av Europas største transplantasjonssykehus. Han opplevde betydelig utvikling i fagfeltet og var i stor grad selv med på å drive utviklingen, med engasjement og enorm arbeidskapasitet. Han var en ypperlig forsker og publiserte et stort antall forskningsartikler. Hallvard var internasjonalt anerkjent og var en hyppig invitert foredragsholder i Europa, USA og Asia. Han brukte nettverket sitt til å invitere internasjonale fagpersoner til Norge. Dette var helt klart med på å heve standarden.

Hallvard spredde humør og betydde mye for arbeidshverdagen vår. han var en pioner i å utdanne kommende nyreleger i transplantasjonsmedisin, og dagens nyreleger husker hans nasjonale kurs. Han framholdt viktigheten av å engasjere flere faggrupper, spesielt sykepleierne, i oppfølging av pasientene. Hans sosiale engasjement i og for avdelingen var enestående. Han inviterte årlig arbeidskollegaer - leger, sykepleier og sekretærer - hjem til seg. Og da var det gourmetmiddag som han alltid hadde laget selv!

Hallvards internasjonale status ble bekreftet da et betydelig transplantasjonstidsskrift, Transplantation, trykket en biografi om ham. Men mest av alt satte Hallvard pris på de daglige møtene med pasientene, som ga uttrykk for at denne joviale doktoren, som snakket trøndersk, virkelig kunne forklare ting og gjøre seg forstått. Vi, hans kolleger, har også lært mye av Hallvard, og setter uendelig stor pris på den tiden vi har hatt sammen med ham.

Publisert: 6. september 2021. Tidsskr Nor Legeforen. DOI: 10.4045/tidsskr.21.0542

(C) Tidsskrift for Den norske legeforening 2023. Lastet ned fra tidsskriftet.no 26. april 2023. 